\title{
Compositional Features and Industrial Assessment of Talcose Rocks of Itagunmodi-Igun Area, Southwestern Nigeria
}

\author{
J. O. Olajide-Kayode ${ }^{1,2^{*}}$, O. A. Okunlola², A. S. Olatunji ${ }^{2}$ \\ ${ }^{1}$ Department of Geosciences, Pan African University Life and Earth Sciences Institute, University of Ibadan, Ibadan, Nigeria \\ ${ }^{2}$ Department of Geology, University of Ibadan, Ibadan, Nigeria \\ Email: *jolugbn@gmail.com
}

How to cite this paper: Olajide-Kayode, J.O., Okunlola, O.A. and Olatunji, A.S. (2018) Compositional Features and Industrial Assessment of Talcose Rocks of Itagunmodi-Igun Area, Southwestern Nigeria. Journal of Geoscience and Environment Protection, 6, 59-77.

https://doi.org/10.4236/gep.2018.61005

Received: December 2, 2017

Accepted: January 27, 2018

Published: January 30, 2018

Copyright $\odot 2018$ by authors and Scientific Research Publishing Inc. This work is licensed under the Creative Commons Attribution International License (CC BY 4.0).

http://creativecommons.org/licenses/by/4.0/

(c) $\underset{\mathrm{EY}}{\mathrm{C}}$ Open Access

\begin{abstract}
Talcose rocks from Itagunmodi and Igun areas within the Ilesa Schist Belt, southwestern Nigeria, were studied to determine their compositional affinities and industrial properties. The talcose bodies occurred as lensoid enclaves closely associated with amphibolites and quartz-mica schist. Petrographic and $\mathrm{X}$-ray diffraction-aided mineralogical studies reveal that the talcose rocks are of the talc-chlorite schist variety composed predominantly of talc (average 73.63\%), subordinate chlorite (average 16.08\%) and accessory lizardite (average 6.5\%). Total whole rock characterization of the samples using Lithium Fusion digestion revealed high mean concentrations of $\mathrm{SiO}_{2}$ (57.53\%), $\mathrm{MgO}$ (24.84\%) and $\mathrm{Fe}_{2} \mathrm{O}_{3}(7.73 \%)$ with significant enrichment of $\mathrm{Ni}$, Co and $\mathrm{Cr}$; and low values of $\mathrm{Ba}, \mathrm{Rb}, \mathrm{Sr}, \mathrm{V}, \mathrm{Cu}$ and $\mathrm{Pb}$. The talc-chlorite schists plotted in the peridotitic komatiite field of the $\mathrm{Al}_{2} \mathrm{O}_{3}-\left(\mathrm{FeO}+\mathrm{TiO}_{2}\right)-\mathrm{MgO}$ diagram. Water Absorption Capacity ranges from $6.25 \%-8.20 \%$, Loss on Ignition is $4.8 \%$ $6.1 \%$ while Linear Shrinkage is $1.25 \%-1.70 \%$ and firing colour is brown to dark-brown. The overall compositional features of the talcose rocks of the area, which were hitherto uncharacterized, show their suitability as raw materials for paint, coloured pottery, ceramic insulation, textile, rubber and plastic manufacture with varying beneficiation requirements. Their high trace element content however, makes them unsuitable for use in pharmaceutical and cosmetic applications.
\end{abstract}

\section{Keywords}

Talc-Chlorite Schist, Petrochemical, Physico-Chemical, Industrial Application

\section{Introduction}

Talcose rocks, which are alteration products of mafic and ultramafic rock units, 
occur intermittently within the N-S trending Proterozoic Schist Belts that are confined to the western half of Nigeria [1] [2]. The Proterozoic schist belts are a suite of supracrustal metasediments infolded into the Nigerian Basement Complex, predominantly of pelitic to semi-pelitic composition and low-medium grade metamorphism. The Ilesa schist belt, located in southwest Nigeria, is one of such belts, hosting the Ifewara fault Zone-which divides the belt into two contrasting lithologies composed mainly of schist (of quartz, biotite, garnet and muscovite mineralogy) and gneisses; along with pelitic schists, quartzites and metabasites on the eastern and western halves respectively [3]. Talc, the essential mineral in these rocks, is an important industrial mineral with wide and varied usage. Notable occurrences of talc bodies in southwest Nigeria include Baba Ode [4], Erin Omu [5], Wonu-Apomu [6], Kumaru [7], Oke-Ila [8], Ile Ife, Ikirun and Esa Oke [9]. Talcose, tremolitic, chloritic and anthophyllitic are the four major mineralogical varieties of talc bodies identified in the Southern area [10]. A number of talcose rock occurrences have been studied for their petrology, petrogenesis [9] [11] and industrial features [12]. The talcose rocks of Itagunmodi-Igun area have, however, not been characterized in terms of their compositional properties. This study therefore involves a mineralogical, petrochemical and physical characterization of these rocks in order to elucidate their compositional characteristics and their potential as industrial raw material.

The study area is located west of Ilesa town, within latitudes $7^{\circ} 30^{\prime}-7^{\circ} 35^{\prime}$ and longitudes $4^{\circ} 37^{\prime}-4^{\circ} 42^{\prime}$ (Figure 1 ), covering an area of about $81 \mathrm{~km}^{2}$. Six representative samples of the outcrops, collected during a geologic mapping on 1:10,000 scale, were prepared for thin section examination under the petrological microscope. Pulverized samples were analysed for elemental composition using Inductively Coupled Plasma Mass Spectrometry employing a Lithium Fusion digestion technique at Bureau Veritas Commodities Ltd., Canada. X-Ray Diffraction analysis was done at University of Poitiers, France to identify the mineral phases present, using a Philips PW 1011 model diffractometer with a scanning rate of $2^{\circ} \mathrm{min}^{-1} \mathrm{~cm}^{-1}$ with a Ni-filtered $\mathrm{Fe} \mathrm{K}$-alpha radiation.

Physical tests conducted include bleaching and firing to determine colour changes, Loss on Ignition (LOI), Water Absorption Capacity (WAC), and Linear Shrinkage (LS). Pulverized samples of the rocks were made into pellets, fired at $870^{\circ} \mathrm{C}$ for 2 hours and bleached with dilute HCL $(0.5-3.0 \mathrm{M})$ for 48 hours. LOI was calculated from the weight loss after heating to $1000^{\circ} \mathrm{C}$. The tests were done at the Geochemistry Laboratory, University of Ibadan.

\section{Field Relationship and Petrographic Features}

Low to medium-grade metamorphic rocks dominated by quartz-biotite schist, with quartzite and amphibolite occur along with the talcose rocks in the study area (Figure 2). The study area lies west of the Ifewara Fault Zone (IFZ) [13] [14], within the Ilesa schist belt; in which talc bodies are known to be closely associated with amphibolites, quartzite and pelitic schists [9]. The talcose rocks 


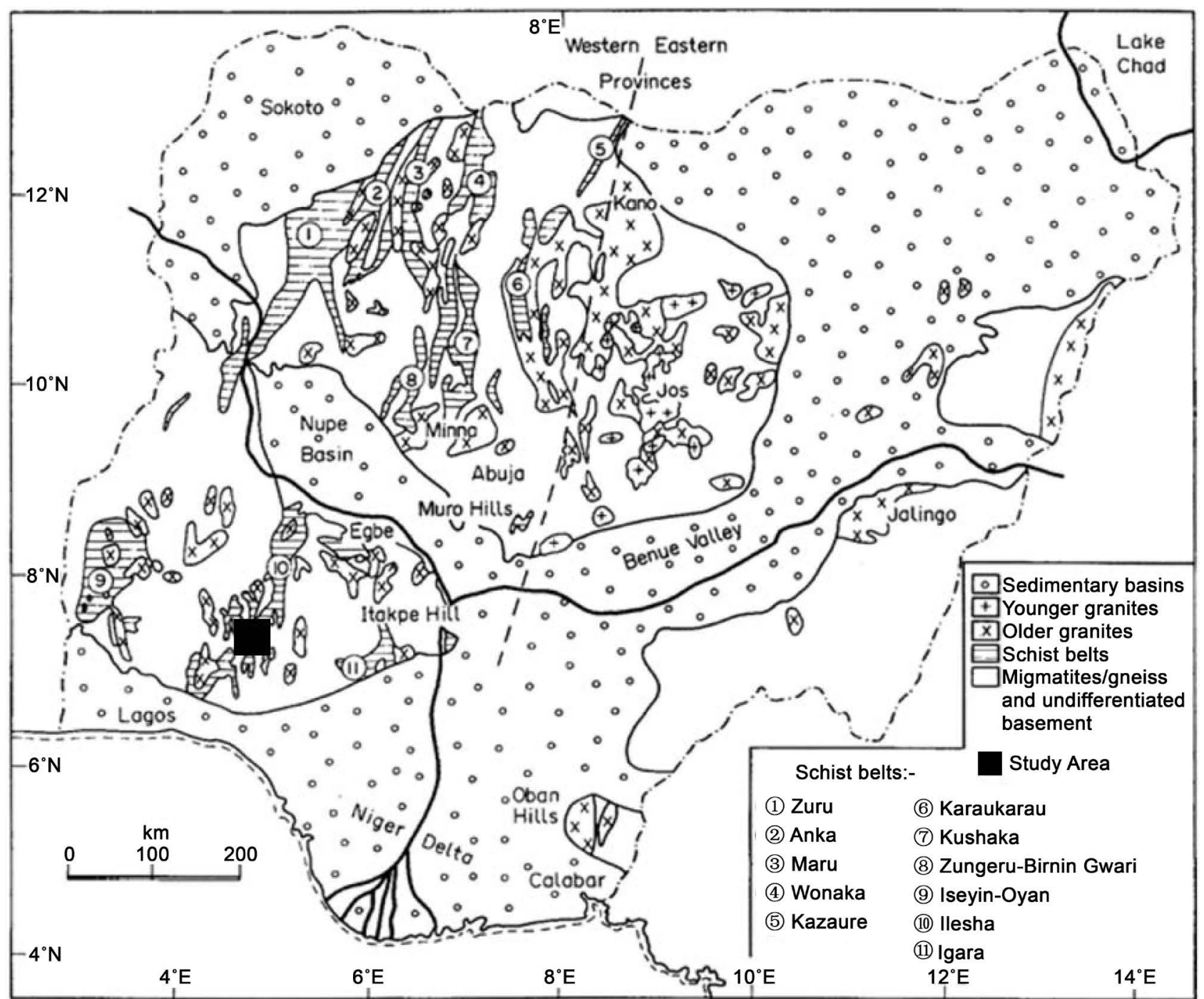

Figure 1. Location of Itagunmodi-Igun within the Proterozoic Schist Belts of Nigeria (after [15]).

occur as discontinuous lensoid enclaves within amphibolites of massive textural variety and quartz-biotite schist in the western and eastern parts of the study area respectively (Figure 2). This is in line with the assertion that talcose rocks of Nigeria associate closely with mafic and ultramafic rocks [9]. In the western half of the study area, they continue intermittently for a strike length of about 6 $\mathrm{km}$ with a north-easterly trend. They were observed occupying low lying areas within the study area, with quartzites and amphibolites forming ridges at the northwestern and central to southern parts of the study area respectively. On outcrop scale, the talcose rocks have a characteristic soapy feel, dirty-white colour and are extremely fine-grained, occurring mostly as poorly exposed outcrops (Figure 3). Few of the talcose rocks contain streaks of brown/rust red colouration believed to result from oxidized iron staining. These can be seen on hand specimen and thin section scales. Hand specimen samples often reveal presence of asbestiform aggregates of lizardite in a decussate textural arrangement. 


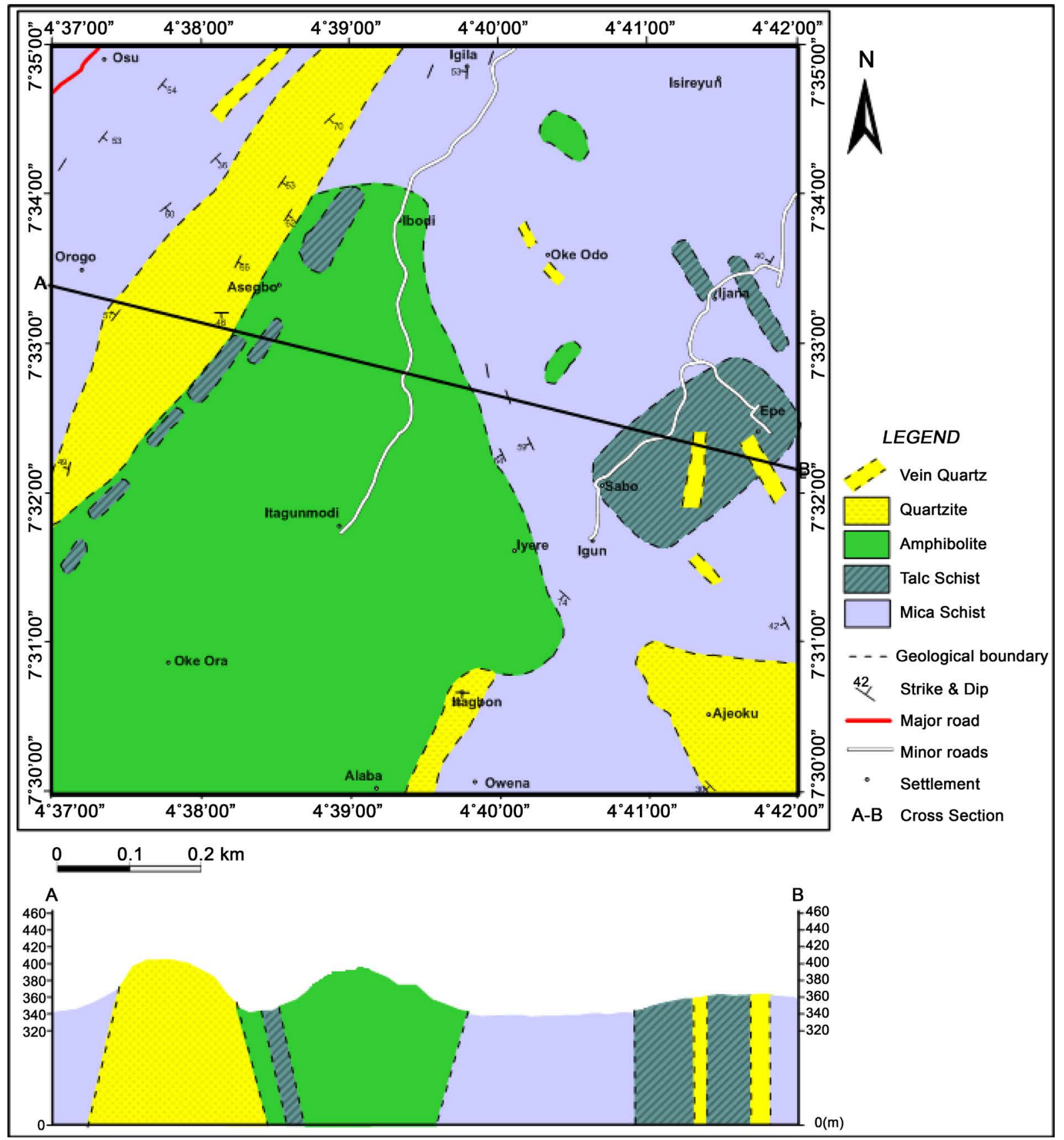

Figure 2. Geologic map of the study area.

\section{Discussion}

Mineralogical and elemental data of the samples were interpreted to unravel the compositional characteristics, petrogenetic affiliations of the rocks, and physicochemical properties were investigated to determine their suitability as industrial materials.

\subsection{Mineralogy}

Thin section study of the rocks revealed a predominant mosaic of talc aggregates 

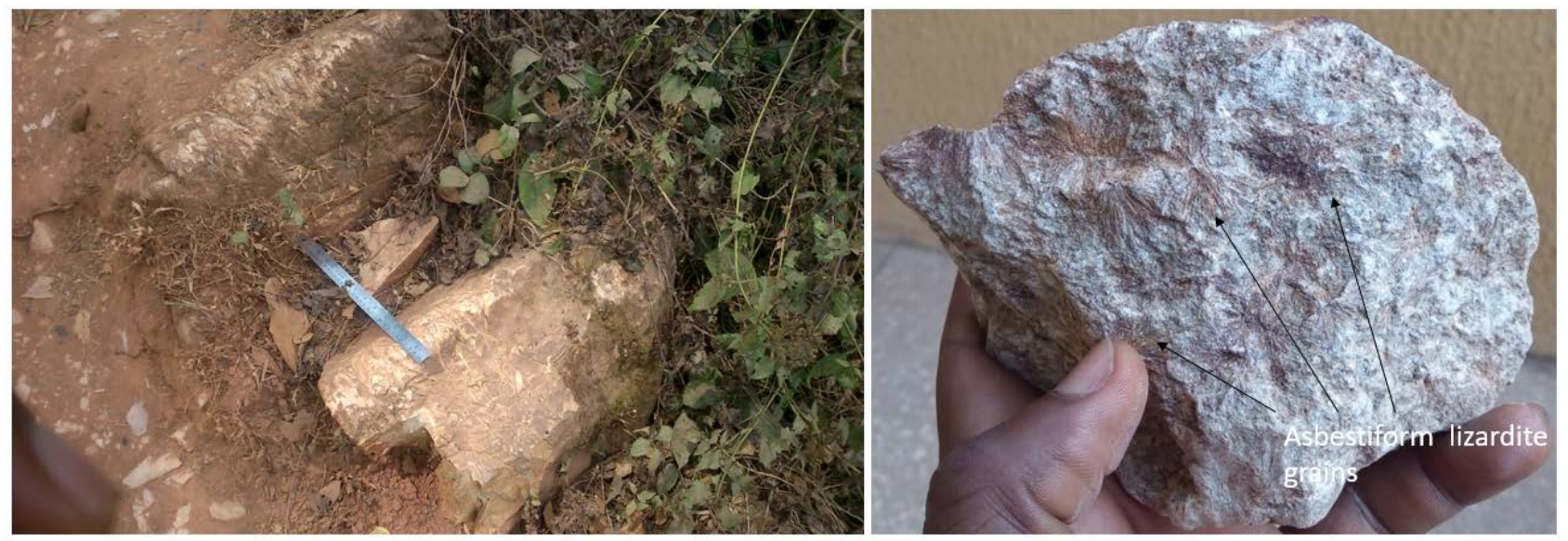

Figure 3. Talc-chlorite schist on outcrop scale and hand specimen (showing radiating lizardite grains) [Ruler length $=30 \mathrm{~cm}]$.

as previously observed in hand specimen. Talc and chlorite are the primary minerals in the talcose rocks, with minor occurrences of lizardite and opaque minerals observed in thin section. X-Ray Diffractograms of the rocks (Figures 4(a)-(f)) revealed conspicuous peaks of talc and chlorite with subordinate hornblende, lizardite and quartz; corroborating the observations obtained from the petrographic studies. Mineralogical composition in the rocks, using diffractogram peak height ratio, indicates that talc in the rocks range from $67.7 \%-91.3 \%$, occurring as mosaics of fibrous grains and constituting the groundmass; chlorite $16 \%$ - 17\%; with long, greenish prismatic grains having moderate relief. Hornblende and lizardite have mean concentrations of $10.46 \%$ and $7.5 \%$ respectively, with the latter observed occurring as long, radiating grains in thin section (Figure 5(a)). Evidence from petrographic and X-Ray diffraction studies indicate the talcose rocks are of the talc-chlorite schist (TCS) variety. Table 1 presents modal composition of the talc-chlorite schists. The talcose rocks in the study area contain higher percentage compositions of talc and chlorite when compared with those of Ilesa-Apomu and Oke-Ila areas. The rocks in IlesaApomu and Oke-Ila contain pyrophyllite/anthophyllite and tremolite/actinolite respectively, which are absent in rocks of the study area (Table 2).

\subsection{Chemistry}

Major oxide concentration in the samples analysed include $\mathrm{SiO}_{2}: 55.26 \%$ 59.15\%, $\mathrm{Al}_{2} \mathrm{O}_{3}: 1.59 \%$ - 3.30\%, $\mathrm{Fe}_{2} \mathrm{O}_{3}: 5.78 \%$ - 11.35\%, MgO: 22.19\% - 26.98\%, $\mathrm{CaO}: 0.24-1.74 \%$ with $\mathrm{TiO}_{2}, \mathrm{MnO}, \mathrm{Na}_{2} \mathrm{O}, \mathrm{K}_{2} \mathrm{O}$ and $\mathrm{P}_{2} \mathrm{O}_{5}$ having concentrations less than $1 \%$ (Table 3). Results of chemical analysis show that the talc-chlorite schists are rich in $\mathrm{SiO}_{2}, \mathrm{MgO}$ and $\mathrm{Fe}_{2} \mathrm{O}_{3}$. The rocks show significant enrichment in $\mathrm{Cr}(1772-3290 \mathrm{ppm})$ and $\mathrm{Ni}(833-1568 \mathrm{ppm})$, and slight enrichment in Co (65 - 88 ppm) (Table 3). Values of other trace elements like $\mathrm{Ba}, \mathrm{Rb}, \mathrm{Sr}, \mathrm{V}, \mathrm{Cu}$ and $\mathrm{Pb}$ are generally low. Compared to the amphibolites and quartz-mica schist associated with the talcose rocks on the field, the $\mathrm{SiO}_{2}$ concentration is the same with amphibolites but slightly lower than the schists. There is significant $\mathrm{Al}_{2} \mathrm{O}_{3}$ 


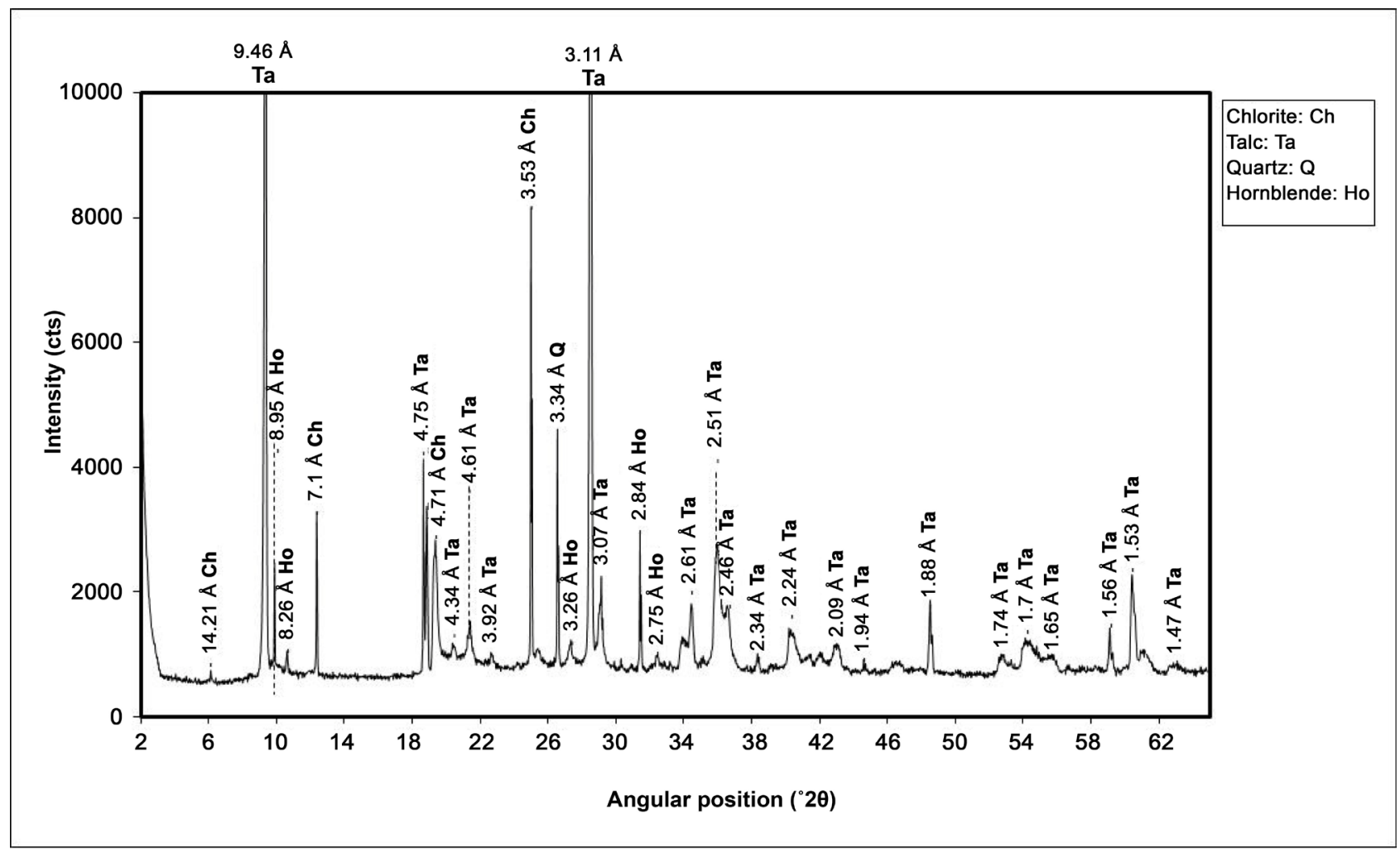

(a)

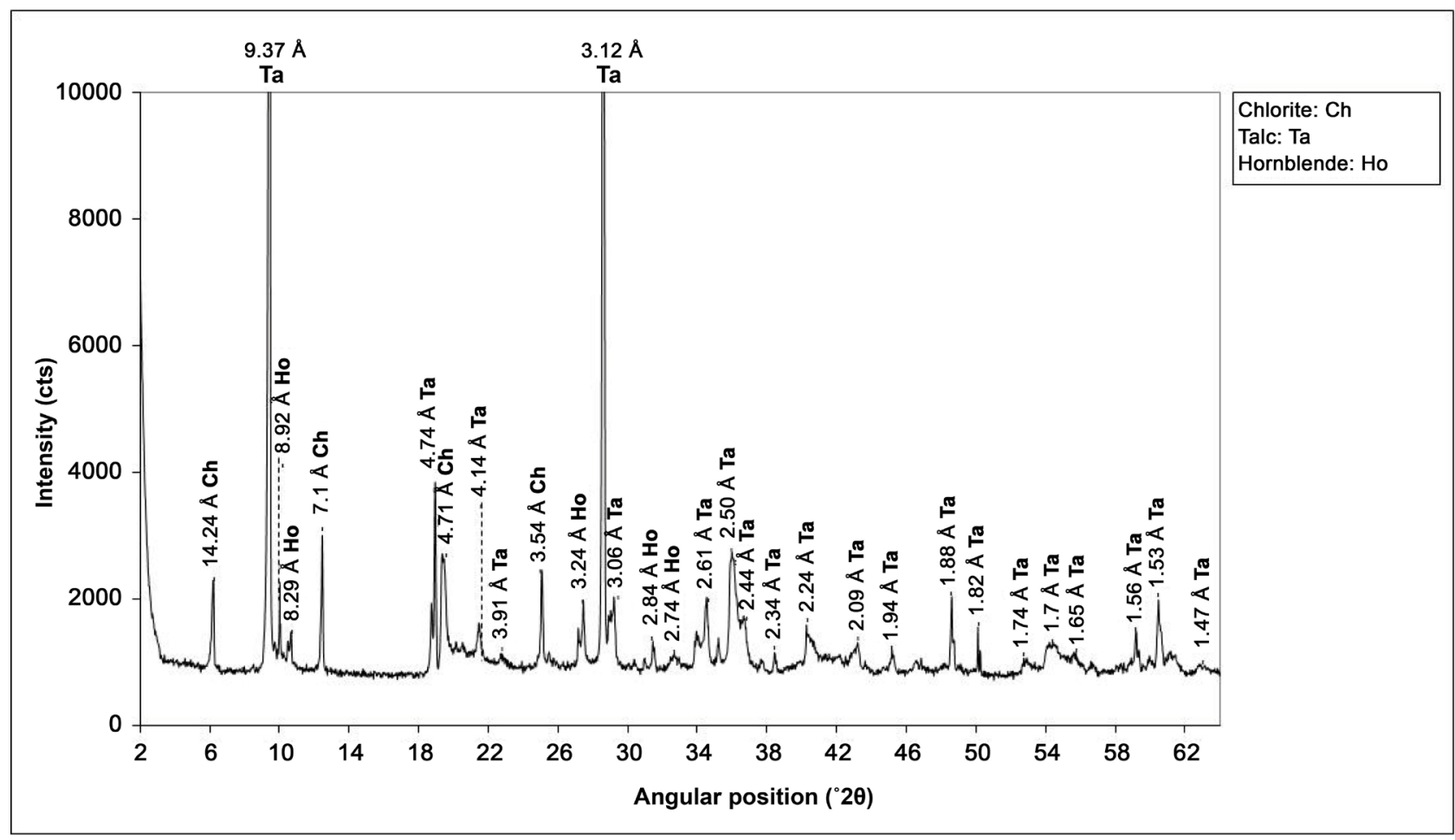

(b) 

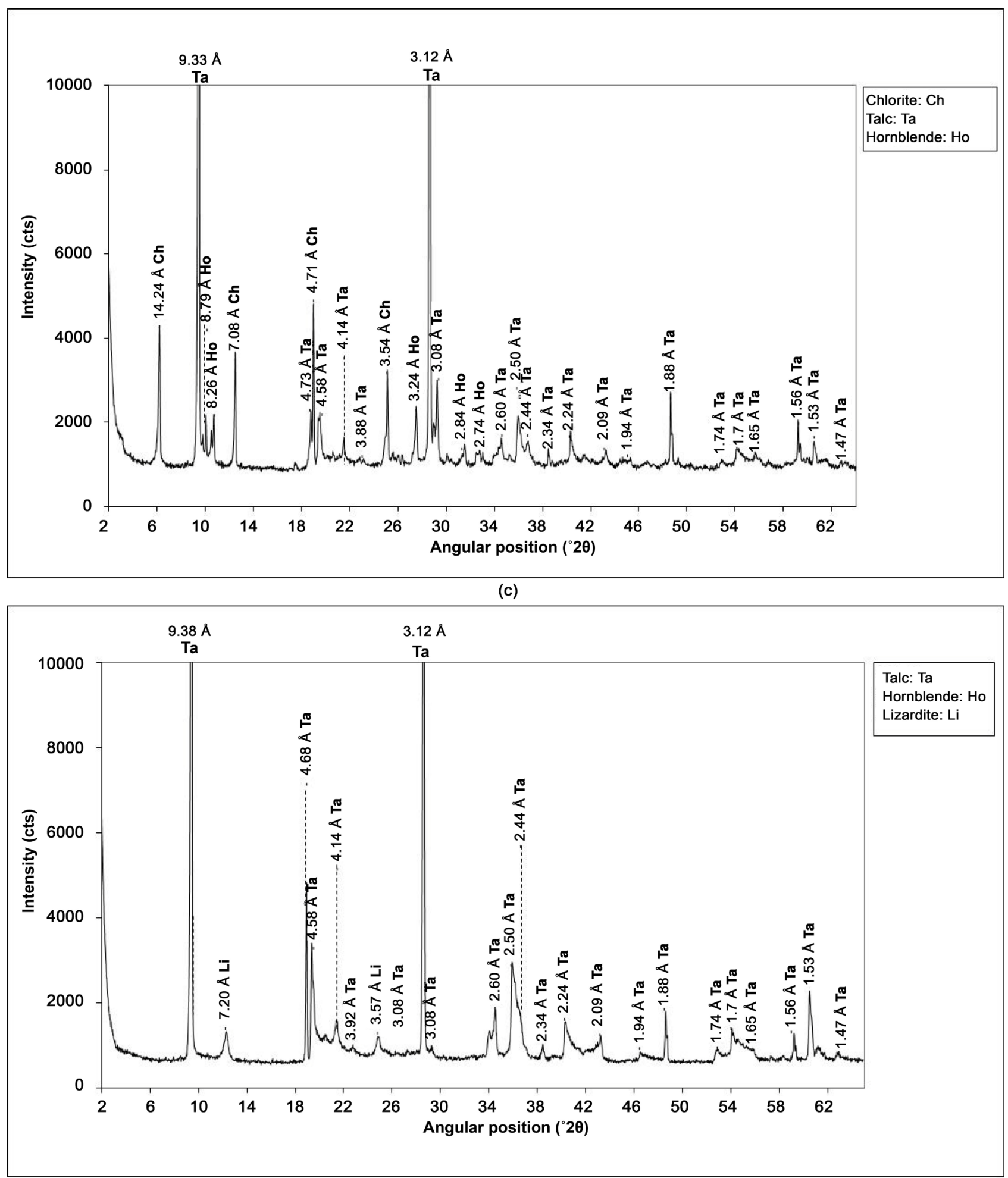

(d) 


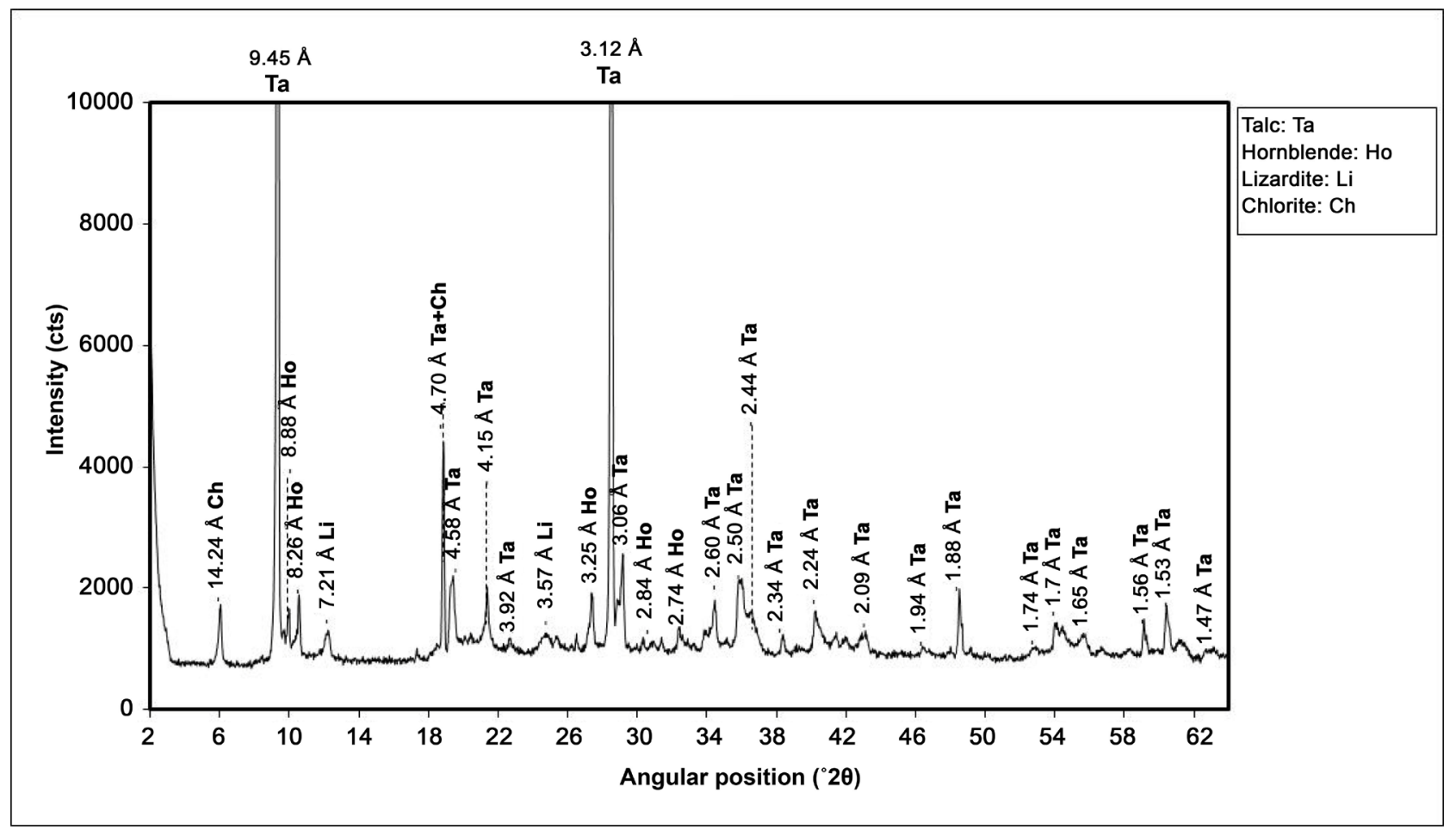

(e)

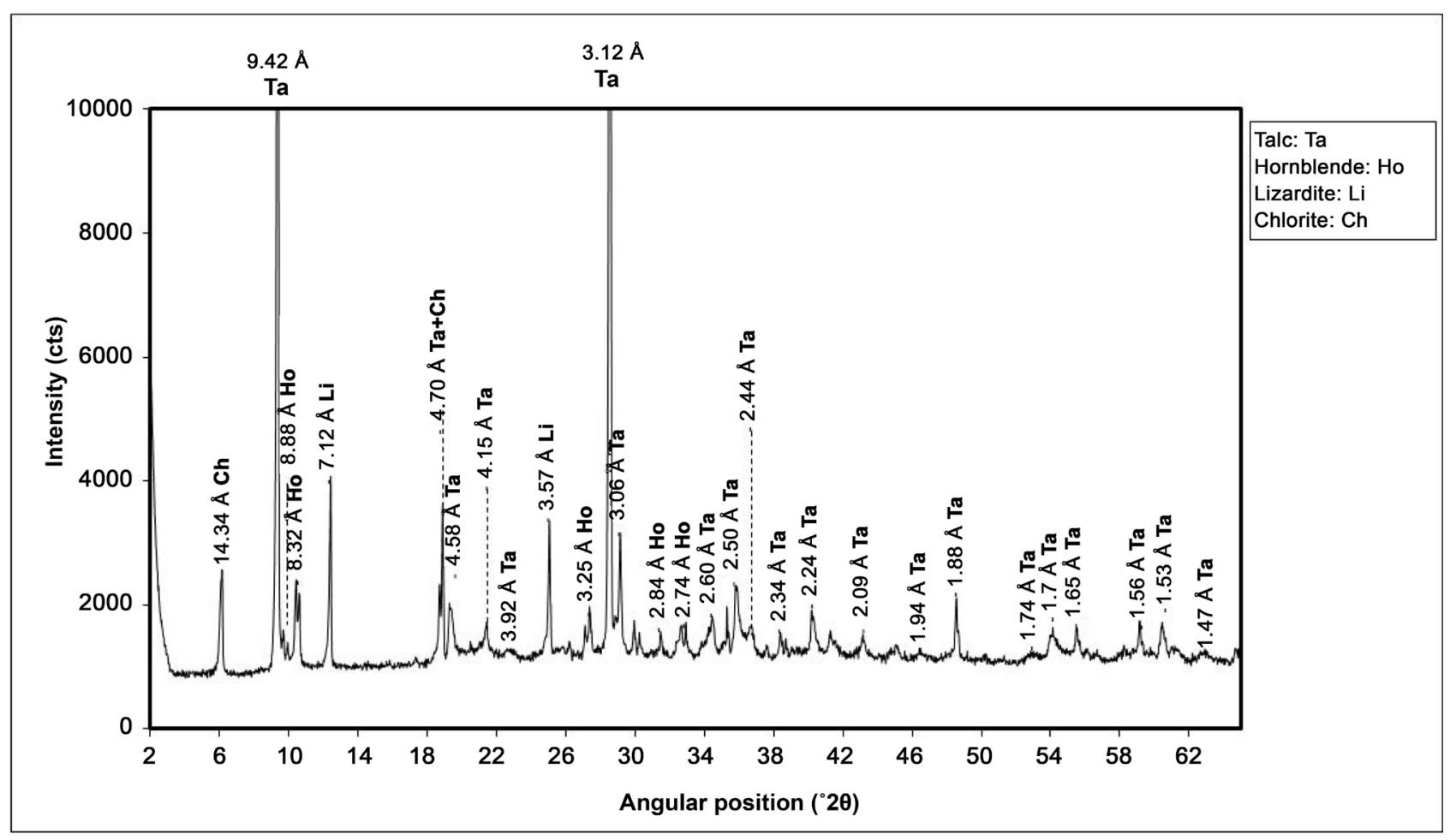

(f)

Figure 4. Diffractograms of the study area talcose rocks depicting predominant talc and chlorite, with accessory hornblende and lizardite. (a) X-Ray Diffractogram for sample 1; (b) X-Ray Diffractogram for sample 2; (c) Diffractogram for sample 3; (d) Diffractogram for sample 4 dominated by talc and chlorite; (e) Diffractogram for sample 5; (f) Prominent talc and chlorite peaks in diffractogram for sample 6. 

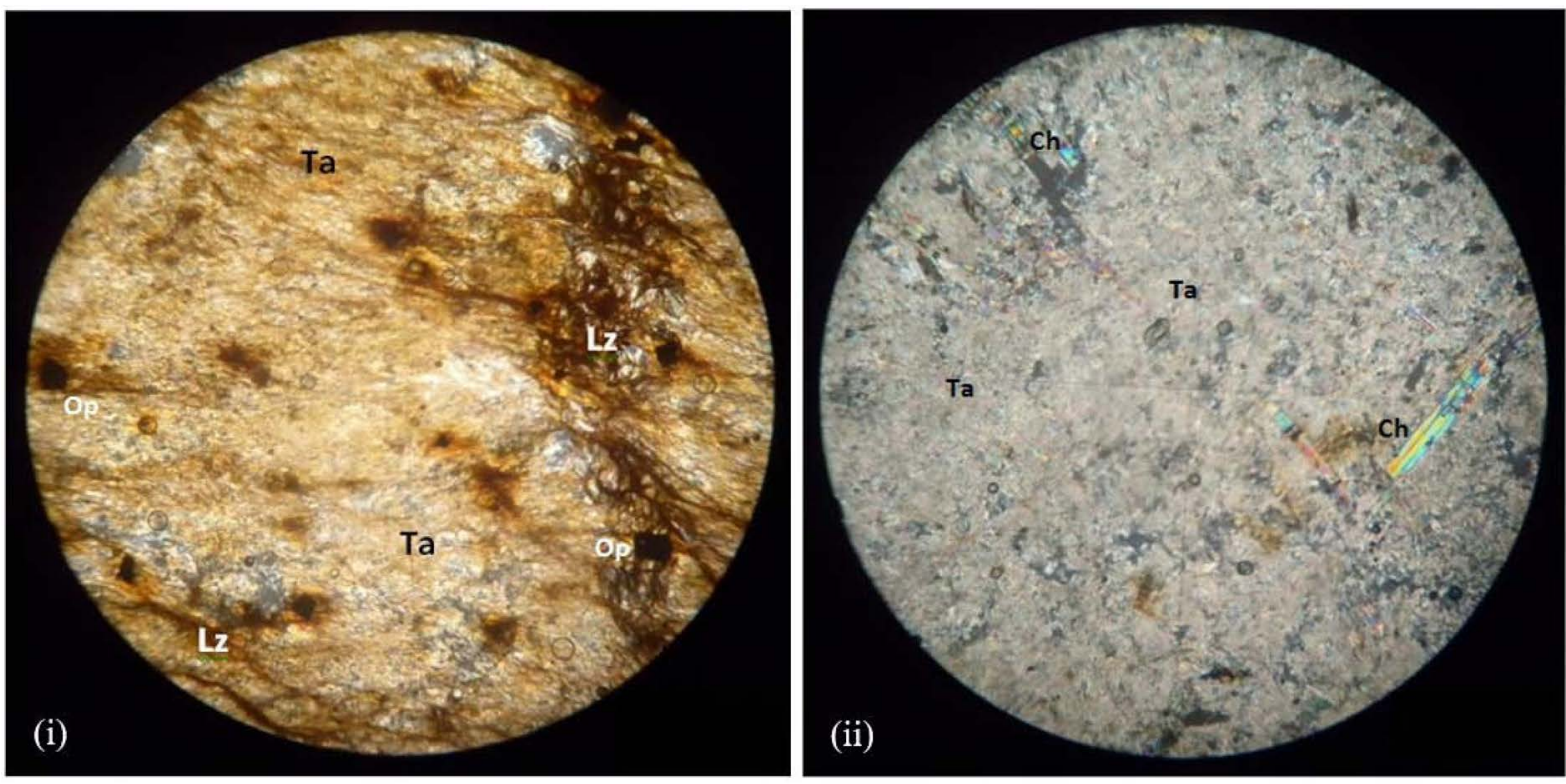

(a)
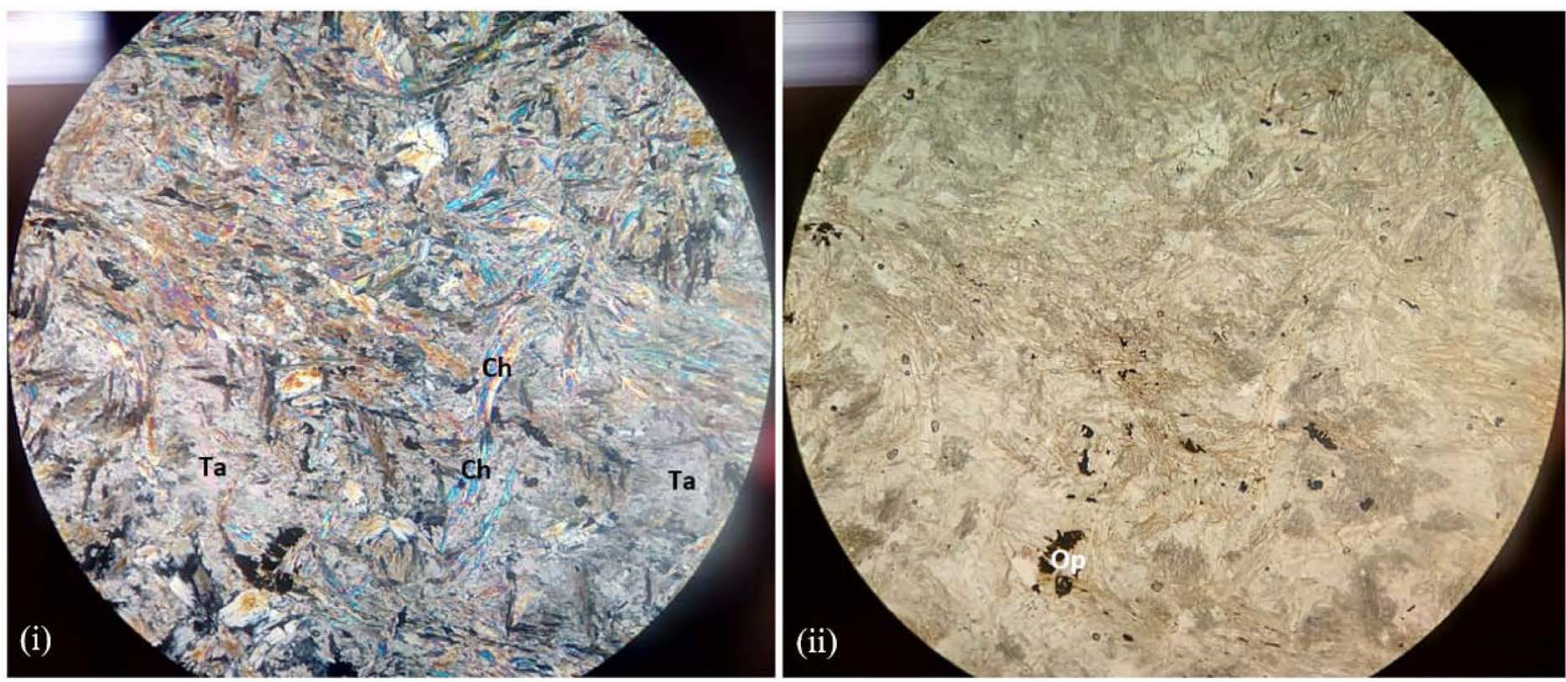

(b)

Figure 5. Talc-chlorite schist in thin section at (a) $40 \times$ and (b) $100 \times$. (a) Photomicrograph of talc-chlorite schist showing predominantly talc with (i) lizardite and (ii) chlorite; (b) (i) Crossed nicol and (ii) plane-polarized photomicrographs of talc-chlorite schist showing inclusions of chlorite and minor opaques in a mosaic of talc.

depletion and $\mathrm{MgO}$ enrichment in the talc-chlorite schists (Table 4). Loss on Ignition in the analysed samples ranged from 4.80 - 6.10 (Table 3).

A comparison of the average major oxide content of the talc-chlorite schist of the study area with talcose rocks from Esie, Oke-Ila, Iseyin and other parts of southwestern Nigeria indicates that silica concentrations are comparatively similar, the magnesia in the talcose rocks of the study area is less than the other areas compared, while it has higher ferric oxide. The alumina content is less than those in talcose rocks of Oke-Ila and Iseyin (Table 5). $\mathrm{Cr}$ and Ni concentrations are higher in the talcose rocks of the study area than those of Esie, Oke-Ila and 
J. O. Olajide-Kayode et al.

Table 1. Modal composition of talc-chlorite schists in the study area.

\begin{tabular}{cccccc}
\hline \multirow{2}{*}{ Sample } & \multicolumn{3}{c}{ Mineralogy (\%) } \\
\cline { 2 - 6 } & Talc & Chlorite & Hornblende & Lizardite & Quartz \\
\hline 1 & 67.7 & 16.1 & 11.9 & - & - \\
2 & 72.0 & 14.2 & 13.3 & - & - \\
3 & 70.0 & 16.7 & 11.3 & - & - \\
4 & 91.3 & - & - & 5.7 & - \\
5 & 69.4 & 16.2 & 8.9 & 5.9 & - \\
6 & 71.4 & 17.2 & 6.9 & 4.9 & 3.2 \\
\hline
\end{tabular}

Table 2. Comparison of modal composition of talcose bodies in the Ilesa area, southwest Nigeria.

\begin{tabular}{|c|c|c|c|c|c|c|c|c|c|c|c|c|c|}
\hline \multirow{2}{*}{ Minerals (\%) } & \multicolumn{6}{|c|}{ Itagunmodi-Igun $^{1}$ (TCS) } & \multicolumn{4}{|c|}{ Ilesa-Apomu ${ }^{2}$ (TCAS/TACS) } & \multicolumn{3}{|c|}{ Oke-Ila $^{3}$ (TTCS) } \\
\hline & 1 & 2 & 3 & 4 & 5 & 6 & 1 & 2 & 3 & 4 & 1 & 2 & 3 \\
\hline Talc & 68 & 72 & 70 & 90 & 69 & 71 & 30 & 32 & 21 & 24 & 58 & 66 & 81 \\
\hline Pyrophyllite & - & - & - & - & - & - & 20 & 20 & 18 & 18 & - & - & - \\
\hline Anthophyllite & - & - & - & - & - & - & 21 & 18 & 28 & 22 & - & - & - \\
\hline Tremolite/Actinolite & - & - & - & - & - & - & - & - & - & - & 18 & 20 & 10 \\
\hline Chlorite & 16 & 14 & 17 & - & 16 & 17 & 14 & 15 & 16 & 20 & 22 & 12 & 8 \\
\hline Hornblende & 12 & 13 & 11 & - & 8 & 6 & - & - & - & - & - & - & - \\
\hline Lizardite & - & - & - & 9 & 6 & 4 & - & - & - & - & - & - & - \\
\hline Clinochlore & - & - & - & - & - & - & 14 & 14 & 16 & 14 & - & - & - \\
\hline Others & 4 & 1 & 2 & 1 & 1 & 2 & 1 & 1 & 1 & 2 & 2 & 2 & 1 \\
\hline
\end{tabular}

${ }^{1}$ This Study (TCS—talc-chlorite schist); ${ }^{2}[9]$ (TCAS/TACS—talc-chlorite-anthophyllite schist/talc-anthophyllite-chlorite schist); ${ }^{3}[8]$ (TTCS—-talc-tremolitechlorite schist).

Table 3. Summary of major and trace element content of Itagunmodi-Igun talc-chlorite schists.

\begin{tabular}{|c|c|c|c|c|c|c|}
\hline Oxide (\%) & 1 & 2 & 3 & 4 & 5 & 6 \\
\hline $\mathrm{SiO}_{2}$ & 58.49 & 55.26 & 58.26 & 55.28 & 58.76 & 59.15 \\
\hline $\mathrm{TiO}_{2}$ & 0.03 & 0.08 & 0.10 & 0.34 & 0.06 & 0.07 \\
\hline $\mathrm{Al}_{2} \mathrm{O}_{3}$ & 1.59 & 2.94 & 3.30 & 2.86 & 2.64 & 2.27 \\
\hline $\mathrm{Fe}_{2} \mathrm{O}_{3}$ & 5.78 & 8.52 & 7.15 & 11.35 & 6.99 & 6.60 \\
\hline $\mathrm{MnO}$ & 0.11 & 0.10 & 0.04 & 0.21 & 0.09 & 0.11 \\
\hline $\mathrm{MgO}$ & 26.98 & 25.72 & 23.93 & 22.19 & 25.17 & 25.02 \\
\hline $\mathrm{CaO}$ & 0.24 & 0.77 & 0.11 & 1.74 & 0.47 & 0.50 \\
\hline $\mathrm{Na}_{2} \mathrm{O}$ & 0.10 & 0.03 & 0.02 & 0.03 & 0.03 & 0.02 \\
\hline $\mathrm{K}_{2} \mathrm{O}$ & 0.08 & BDL & 0.04 & 0.02 & BDL & 0.02 \\
\hline $\mathrm{P}_{2} \mathrm{O}_{5}$ & 0.03 & $\mathrm{BDL}$ & 0.01 & 0.03 & $\mathrm{BDL}$ & 0.02 \\
\hline LOI & 5.60 & 5.50 & 6.10 & 5.00 & 4.80 & 5.30 \\
\hline
\end{tabular}




\section{Continued}

\begin{tabular}{|c|c|c|c|c|c|c|}
\hline Sum & 99.54 & 99.55 & 99.60 & 99.58 & 99.56 & 99.57 \\
\hline \multicolumn{7}{|c|}{ Trace elements (ppm) } \\
\hline $\mathrm{Ba}$ & 17 & 24 & 8 & 38 & 16 & 19 \\
\hline Co & 79 & 72 & 65 & 88 & 86 & 65 \\
\hline $\mathrm{Cr}$ & 1772 & 3290 & 2551 & 2633 & 2189 & 2483 \\
\hline $\mathrm{Cu}$ & 3 & 19 & 17 & 70 & 11 & 35 \\
\hline $\mathrm{Ni}$ & 1568 & 1328 & 1097 & 833 & 1532 & 1117 \\
\hline $\mathrm{Pb}$ & 0.7 & 0.2 & 2 & 0.5 & 0.4 & 0.5 \\
\hline $\mathbf{R b}$ & 10 & 0.3 & 2 & 0.8 & 0.7 & 2 \\
\hline $\mathrm{Sr}$ & 8 & 10 & 5 & 35 & 6 & 7 \\
\hline $\mathrm{V}$ & 33 & 39 & 60 & 65 & 45 & 44 \\
\hline $\mathrm{Zn}$ & 6 & 17 & 9 & 19 & 12 & 34 \\
\hline
\end{tabular}

Table 4. Comparisons of elemental concentrations in talc-chlorite schists with associated amphibolite and quartz-mica schist.

\begin{tabular}{|c|c|c|c|c|c|c|}
\hline \multirow{2}{*}{ Major Oxides (\%) } & \multicolumn{2}{|c|}{ Talc-chlorite schist } & \multicolumn{2}{|c|}{ Amphibolites } & \multicolumn{2}{|c|}{ Quartz-mica schist } \\
\hline & Mean & Range & Mean & Range & Mean & Range \\
\hline $\mathrm{SiO}_{2}$ & 57.53 & $55.26-59.15$ & 55.11 & $49.67-67.19$ & 63.65 & $50.05-67.46$ \\
\hline $\mathrm{TiO}_{2}$ & 0.11 & $0.03-0.34$ & 1.15 & $0.72-1.36$ & 0.98 & $0.82-1.35$ \\
\hline $\mathrm{Al}_{2} \mathrm{O}_{3}$ & 2.60 & $1.59-3.30$ & 13.26 & $12.13-15.16$ & 14.60 & $12.17-15.31$ \\
\hline $\mathrm{Fe}_{2} \mathrm{O}_{3}$ & 7.73 & $5.78-11.35$ & 9.73 & $6.29-11.15$ & 7.48 & $6.19-11.13$ \\
\hline $\mathrm{MnO}$ & 0.11 & $0.04-0.21$ & 0.17 & $0.10-0.20$ & 0.12 & $0.10-0.20$ \\
\hline $\mathrm{MgO}$ & 24.84 & $22.19-26.98$ & 6.06 & $1.64-7.24$ & 2.93 & $1.60-7.21$ \\
\hline $\mathrm{CaO}$ & 0.64 & $0.11-1.74$ & 7.98 & $1.50-10.96$ & 3.52 & $1.51-10.32$ \\
\hline $\mathrm{Na}_{2} \mathrm{O}$ & 0.04 & $0.02-0.10$ & 1.40 & $1.00-2.33$ & 1.80 & $1.01-2.08$ \\
\hline $\mathrm{K}_{2} \mathrm{O}$ & 0.03 & $0.01-0.08$ & 2.18 & $0.66-6.66$ & 2.26 & $1.12-2.71$ \\
\hline $\mathrm{P}_{2} \mathrm{O}_{5}$ & 0.02 & $0.01-0.03$ & 0.37 & $0.11-1.09$ & 0.16 & $0.10-0.20$ \\
\hline \multicolumn{7}{|l|}{ Trace Elements (ppm) } \\
\hline $\mathrm{Ba}$ & 20 & $8-38$ & 840 & $238-2732$ & 567 & $417-638$ \\
\hline Co & 76 & $65-88$ & 3 & $1-7$ & 21 & $13-43$ \\
\hline $\mathrm{Cr}$ & 2486 & $1772-3290$ & 266 & $90-320$ & 145 & $70-330$ \\
\hline $\mathrm{Cu}$ & 26 & $3-70$ & 34 & $22-41$ & 26 & $21-46$ \\
\hline $\mathrm{Ni}$ & 1246 & $833-1568$ & 81 & $29-102$ & 48 & $27-100$ \\
\hline $\mathrm{Pb}$ & 0.72 & $0.2-2$ & 16 & $3-25$ & 7 & $3-19$ \\
\hline $\mathrm{Rb}$ & 2 & $0.3-10$ & 76 & $17-242$ & 81 & $28-101$ \\
\hline $\mathrm{Sr}$ & 12 & $5-35$ & 556 & $216-916$ & 293 & $214-560$ \\
\hline $\mathrm{V}$ & 48 & $33-65$ & 207 & $100-263$ & 139 & $96-261$ \\
\hline $\mathrm{Zn}$ & 16 & $6-34$ & 39 & $20-52$ & 46 & $40-52$ \\
\hline
\end{tabular}


Table 5. Comparison of elemental composition of Itagunmodi-Igun talc-chlorite schists with talcose rocks from other parts of Nigeria.

\begin{tabular}{|c|c|c|c|c|c|c|c|c|c|c|}
\hline \multirow{2}{*}{$\begin{array}{c}\text { Oxides } \\
\text { (\%) }\end{array}$} & \multicolumn{2}{|c|}{ This study } & \multicolumn{2}{|r|}{$\mathrm{Esie}^{1}$} & \multicolumn{2}{|r|}{ Oke-Ila ${ }^{2}$} & \multicolumn{2}{|c|}{ Iseyin (TTCS) ${ }^{3}$} & \multicolumn{2}{|c|}{ SW Nigeria (TTAS) ${ }^{4}$} \\
\hline & Mean & Range $(n=6)$ & Mean & Range $(n=12)$ & Mean & Range $(n=40)$ & Mean & Range $(n=10)$ & Mean & Range \\
\hline $\mathrm{SiO}_{2}$ & 57.53 & $55.26-59.15$ & 56.21 & $50.48-58.30$ & 52.30 & $44.82-56.52$ & 54.70 & $53.61-55.35$ & 55.01 & $46.82-55.37$ \\
\hline $\mathrm{Al}_{2} \mathrm{O}_{3}$ & 2.60 & $1.59-3.30$ & 1.66 & $0.50-5.54$ & 3.14 & $2.66-5.49$ & 3.54 & $1.86-4.84$ & 2.52 & $1.19-2.86$ \\
\hline $\mathrm{MnO}$ & 0.11 & $0.04-0.21$ & 0.10 & $0.03-0.18$ & 0.18 & $0.12-0.20$ & 0.16 & $0.10-0.25$ & 0.05 & $0.04-0.13$ \\
\hline $\mathrm{MgO}$ & 24.84 & $22.19-26.98$ & 29.71 & $26.09-31.35$ & 26.98 & $20.54-28.15$ & 27.20 & $22.06-30.38$ & 30.04 & $29.13-32.04$ \\
\hline $\mathrm{CaO}$ & 0.64 & $0.11-1.74$ & 0.16 & $0.04-0.37$ & 7.40 & $6.28-8.66$ & 4.43 & $2.76-5.32$ & 1.50 & $0.41-4.47$ \\
\hline $\mathrm{Na}_{2} \mathrm{O}$ & 0.04 & $0.02-0.10$ & 0.16 & $0.12-0.25$ & 0.05 & $0.03-0.08$ & 0.22 & $0.16-0.32$ & 0.01 & $0.01-0.02$ \\
\hline $\mathrm{P}_{2} \mathrm{O}_{5}$ & 0.02 & $0.01-0.03$ & 0.02 & $0.01-0.03$ & 0.02 & $0.01-0.05$ & 0.02 & $0.02-0.02$ & 0.06 & $0.05-0.13$ \\
\hline LOI & 5.38 & $4.80-6.10$ & 4.63 & $3.90-6.07$ & 4.54 & $3.75-5.20$ & 2.99 & $1.82-4.88$ & 6.00 & $3.60-5.41$ \\
\hline Sum & 99.57 & - & 99.60 & - & 99.86 & - & 97.99 & - & 99.71 & - \\
\hline \multicolumn{11}{|c|}{ Trace Elements (ppm) } \\
\hline Co & 76 & $65-87.9$ & 70 & $42-81$ & 66 & $52-79$ & 71 & $52-80$ & - & - \\
\hline $\mathrm{Cr}$ & 2486 & $1772-3290$ & 1969 & $1330-2690$ & 1629 & $608-2310$ & 826 & $806-897$ & 2000 & - \\
\hline $\mathrm{Ni}$ & 1246 & $833-1568$ & 1370 & $637-1870$ & 774 & $639-979$ & 1278 & $1034-1702$ & 1500 & - \\
\hline $\mathrm{Zn}$ & 16 & $6-34$ & 1120 & $66-182$ & 78 & $81-96$ & 69 & $58-82$ & - & - \\
\hline
\end{tabular}

${ }^{1}[11] ;{ }^{2}[8] ;{ }^{3}[16] ;{ }^{4}[17]$.

Iseyin, while $\mathrm{Zn}$ and Co concentrations are less. The relative chemical mobility of $\mathrm{Na}$, Ca and $\mathrm{K}$ during secondary alteration processes [9] is visible in strong depletions of oxides of these elements relative to amphibolites and quartz-mica schists having field relationships with the talcose rocks.

The low values of $\mathrm{Ba}, \mathrm{Sr}$ and $\mathrm{Rb}$ are probably due to their chemical instability during secondary alteration processes [9]. $\mathrm{Cr}$ and $\mathrm{Ni}$ are chemically immobile, even under hydrothermal alteration conditions, and this explains their enrichment in the talcose rocks in the study area. $\mathrm{Zr}$ and $\mathrm{Sr}$ also have low values in the talcose rocks likely due to the absence of mineralogical phases in the rock to host them.

On the $\mathrm{Al}_{2} \mathrm{O}_{3}-\left(\mathrm{FeO}+\mathrm{TiO}_{2}\right)-\mathrm{MgO}$ plot of [18], the talc-chlorite schist plot in the peridotitic komatiite field (Figure 6). This assertion is supported by the low concentrations of aluminium and potassium oxides, and the high magnesium content in the rocks (Table 3 ). The talcose bodies were therefore, most likely metamorphosed from a komatiite; an ultramafic mantle-derived volcanic rock. The talcose rocks also plot within the komatiitic field on [19] $\mathrm{Al}_{2} \mathrm{O}_{3}$ vs. $\mathrm{FeO}$ / $(\mathrm{FeO}+\mathrm{MgO})$ plot (Figure 7). All the samples plot close to the talc field in the $\mathrm{CaO}-\mathrm{SiO}_{2}-\mathrm{MgO}$ plot (Figure 8). 


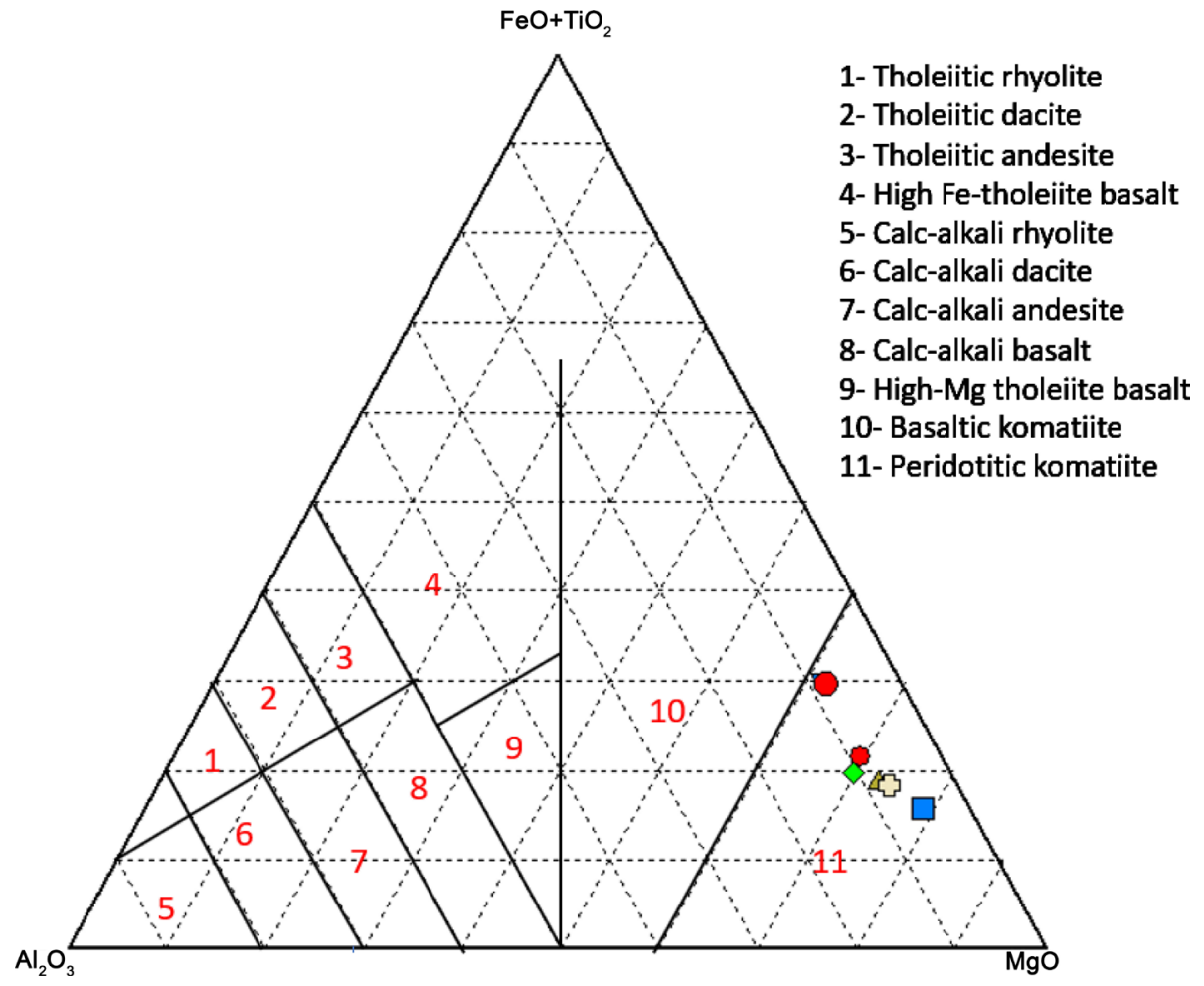

Figure 6. Plot of Itagunmodi-Igun talc-chlorite schist on $\mathrm{Al}_{2} \mathrm{O}_{3}-\left(\mathrm{FeO}+\mathrm{TiO}_{2}\right)-\mathrm{MgO}$ plot of [18].

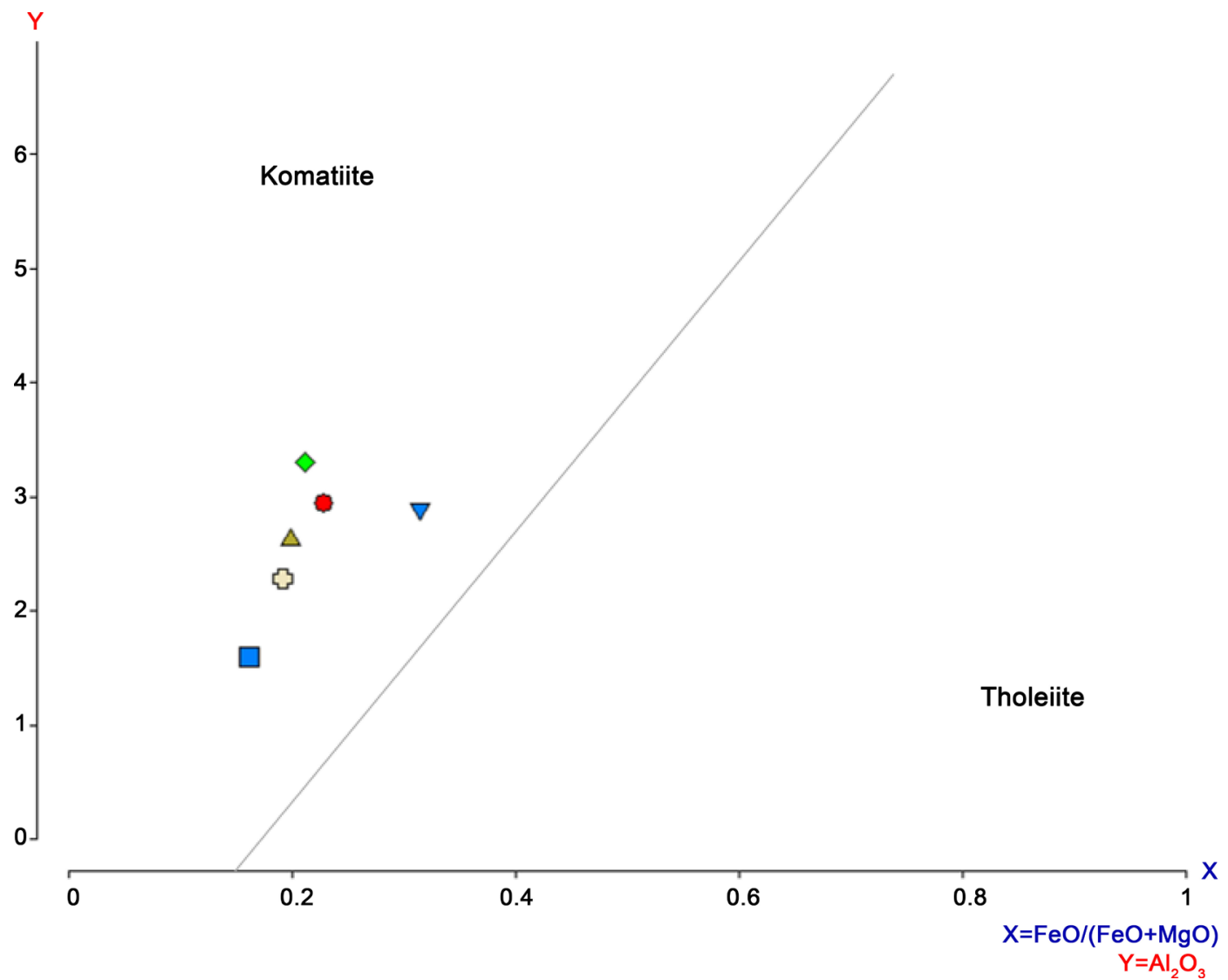

Figure 7. $\mathrm{Al}_{2} \mathrm{O}_{3}$ vs. $\mathrm{FeO} /(\mathrm{FeO}+\mathrm{MgO})$ plot of [19]. 


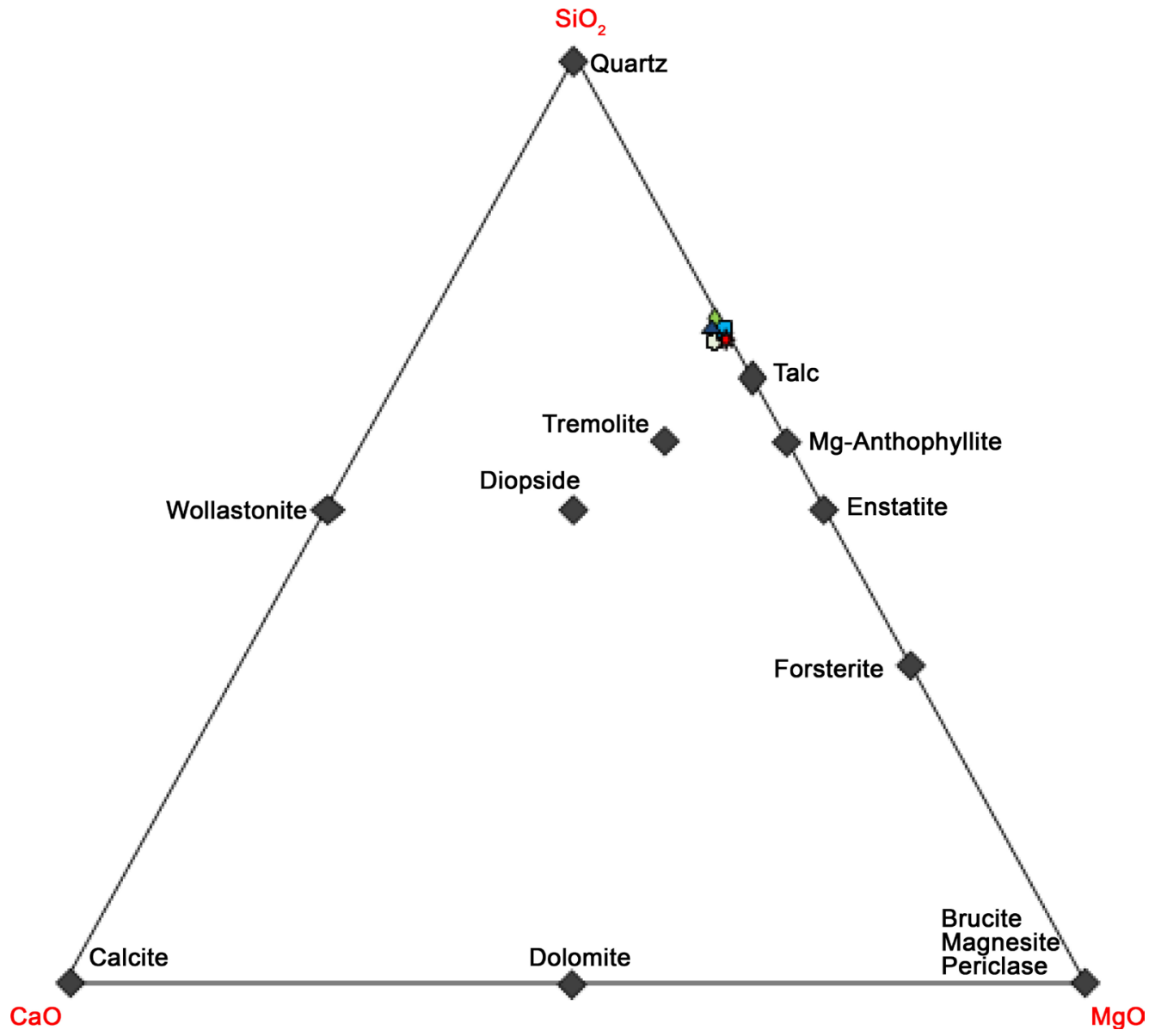

Figure 8. $\mathrm{CaO}-\mathrm{SiO}_{2}-\mathrm{MgO}$ plot for Itagun-Igun talcose rocks.

\subsection{Industrial Appraisal}

Talc, as an industrial mineral, has found application in the manufacture of various products such as ceramics, cosmetics, rubber, roofing sheets, paper, pharmaceuticals, paint and insecticides [20]. The suitability of talc for industrial application is largely a function of its physico-chemical properties.

Pulverized samples of the talc-chlorite schist were made into pellets and fired at $870^{\circ} \mathrm{C}$ for 2 hours to determine Linear Shrinkage (LS), bleached with dilute HCL for 48 hours and then submerged in water for 24 hours. LOI was calculated from the weight lost after heating to $1000^{\circ} \mathrm{C}$. Water Absorption Capacity (WAC) was estimated by determining the percentage volume increase after soaking the pellets in water, while the reduction in diameter of the fired pellets compared to the unfired ones gave their LS values. WAC for the samples ranged between 6.25 and $8.20 \%$, LS: $1.25 \%-1.70 \%$, and LOI: $4.80-6.10$. Powders of the talc-chlorite schists bleached from grey and light brown to brown and dark brown (Table 6).

A comparison of industrial properties of talcose rocks of the study area with those of other parts of south western Nigeria indicates that the WAC values for rocks from the study area are lower than those from Wonu-Apomu, Erin-Omu, Iseyin and Baba Ode; but higher than Oke-Ila area. The range of LS value of the 
other areas are wider than those of the study area, while the LOI are comparable with talcose rocks in Iseyin and Wonu-Apomu (Table 7). Average talc composition in the Itagunmodi-Iguntalc-chlorite schist is comparable to industrial and pharmaceutical grade Luzenac talc deposit in France [21] but significantly higher than the talc composition of Lumphurm [22] and Pitchbury [23] textile- , and rubber-grade talc deposits respectively. Mean chlorite compositions in the Pitchbury, Lumphurm and Itagunmodi-Igun talcose bodies are approximately the same (Table 8).

Table 6. Physical properties of talc-chlorite schists of the study area.

\begin{tabular}{|c|c|c|c|c|c|c|c|}
\hline \multicolumn{2}{|c|}{ Parameter/Sample } & 1 & 2 & 3 & 4 & 5 & 6 \\
\hline \multicolumn{2}{|c|}{ WAC (\%) } & - & 6.25 & 6.30 & 8.14 & 8.20 & 5.35 \\
\hline \multicolumn{2}{|c|}{ LS (\%) } & - & 1.70 & 1.40 & 1.25 & 1.25 & 1.60 \\
\hline \multicolumn{2}{|c|}{ LOI (\%) } & - & 5.5 & 6.1 & 5.0 & 4.8 & 5.3 \\
\hline \multirow{2}{*}{ Colour } & Unfired & - & Light brown & Grey & Light brown & Light brown & Dark grey \\
\hline & Fired & - & Dark brown & Brown & Dark brown & Dark brown & Dark brown \\
\hline
\end{tabular}

Table 7. Comparison of physical properties of talcose rocks in the study area with other parts of SW Nigeria.

\begin{tabular}{|c|c|c|c|c|c|c|c|}
\hline \multicolumn{2}{|c|}{ Parameter } & Present study & Wonu-Apomu/Ilesa ${ }^{1}$ & Erin-Omu ${ }^{2}$ & Iseyin $^{3}$ & Oke-Ila ${ }^{4}$ & Baba-Ode $^{5}$ \\
\hline \multicolumn{2}{|c|}{ WAC (\%) } & $5.35-8.20$ & $8.05-10.00$ & $13.25-16.25$ & $6.96-11.65$ & $4.21-5.80$ & $15.14-18.25$ \\
\hline \multicolumn{2}{|c|}{ LS (\%) } & $1.25-1.70$ & $2.33-4.40$ & $1.01-1.81$ & $0.25-2.0$ & $2.45-3.50$ & $1.01-1.52$ \\
\hline \multicolumn{2}{|c|}{ LOI (\%) } & $4.8-6.1$ & $4.21-5.27$ & $2.87-4.11$ & $1.45-6.03$ & $3.75-5.28$ & $4.25-4.41$ \\
\hline \multirow{2}{*}{ Colour } & Unfired & L/Brown-grey & Green/brown/grey & - & - & - & - \\
\hline & Fired & Brown-D/Brown & Red/yellow/cream & - & - & - & - \\
\hline
\end{tabular}

${ }^{1}[9] ;{ }^{2}[5] ;{ }^{3}[16] ;{ }^{4}[8] ;{ }^{5}[4]$.

Table 8. Comparison of mineralogical composition of Itagun-Igun talcose rocks with industrial grade talcose deposits.

\begin{tabular}{|c|c|c|c|c|c|c|c|c|c|c|c|c|}
\hline \multirow{2}{*}{ Minerals (\%) } & \multicolumn{8}{|c|}{ This study } & \multicolumn{4}{|c|}{ Reference samples } \\
\hline & 1 & 2 & 3 & 4 & 5 & 6 & Range & Mean & A & b (i) & b (ii) & $\mathrm{C}$ \\
\hline Talc & 68 & 72 & 70 & 90 & 69 & 71 & $68-90$ & 73 & 41 & 65 & 91 & 43 \\
\hline Pyrophyllite & - & - & - & - & - & - & - & - & - & - & - & - \\
\hline Anthophyllite & - & - & - & - & - & - & - & - & 4 & - & - & 6 \\
\hline Tremolite/Actinolite & - & - & - & - & - & - & - & - & 31 & - & - & 33 \\
\hline Chlorite & 16 & 14 & 17 & - & 16 & 17 & $14-17$ & 16 & 12 & 6 & 1 & 13 \\
\hline Hornblende & 12 & 13 & 11 & - & 8 & 6 & $6-12$ & 10 & - & - & - & - \\
\hline Lizardite & - & - & - & 9 & 6 & 4 & $4-9$ & 6.3 & - & - & - & - \\
\hline Muscovite & - & - & - & - & - & - & - & - & 2 & - & 2 & - \\
\hline Dolomite & - & - & - & - & - & - & - & - & - & 15 & 3.5 & 1.7 \\
\hline Others (opaques, quartz) & 4 & 1 & 2 & 1 & 1 & 2 & $1-4$ & 1.8 & 4 & 3 & - & 3.5 \\
\hline
\end{tabular}

${ }^{a}$ Lumphurm Deposit; Textile grade [22]; ${ }^{b}$ Luzenac Talc; (i) Industrial grade (ii) Pharmaceutical grade [21]; 'Pitchbury Talc, Rubber grade [23]. 
Talc is a versatile industrial mineral useful in the manufacture of paints, cosmetics, pharmaceuticals, detergents and agricultural products. Talc, when used as a cement substitute, has less energy-intensive production requirement than Portland Cement and absorbs far more carbon dioxide as it hardens, thereby leaving a negative carbon footprint.

On the ISO Quality Specification for talc [24], the talcose rocks of the study area fall in Types $\mathrm{C}$ and $\mathrm{D}$ for wt\% talc content (with values ranging from $68 \%$ $91 \%$ ), and Type A for wt $\%$ LOI at $1000^{\circ} \mathrm{C}$ (with values $4.8 \%-6.1 \%$ ).

When fired, the talcose rocks are brown to dark brown in colour, making them suitable as materials for insulation ceramics and in coloured pottery, but not as white wares and enamels as these require a white firing colour and an average of $6 \% \mathrm{CaO}$ [25] [26]. The maturing temperature of the talc could be improved as a result of the presence of aluminium-rich chlorite, thereby increasing its usability for ceramic manufacture. Also, the absence of iron minerals in the talc schists is advantageous as they are known to cause spotting in ceramics [6]. They will also find use in the manufacture of plastics, textiles, paint, rubber and roofing materials [25] [26] [27] [28].

Paint manufacture requires an $\mathrm{Al}_{2} \mathrm{O}_{3}$ composition of ca $2 \%, \mathrm{MgO}+\mathrm{SiO}_{2}$ (ca. $75 \%)$ and LOI (4\% - 8\%) [25] [26]; all criteria which the talcose rocks of the study area satisfy. For rubber manufacture, useful talc raw material will have no gritty particles and be composed of low $\mathrm{MnO}$ and $\mathrm{CaO}$ values [25] [26]. The talc-chlorite schists are very fine when pulverized and have low concentrations of $\mathrm{CaO}$ and $\mathrm{MnO}$ (Table 3). However, they areunsuitable for paper manufacture as the requirements include white colour, fine grain, no mica content and very low $\mathrm{Fe}_{2} \mathrm{O}_{3}$ and $\mathrm{CaO}$ contents [28]. The talc-chlorite schists have high $\mathrm{Fe}_{2} \mathrm{O}_{3}$ content and are brown to dark brown in colour post-bleaching. They also do not meet the criteria for refractory materials [29], as their $\mathrm{Fe}_{2} \mathrm{O}_{3}$ and $\mathrm{SiO}_{2}$ contents are too high. To be desirable as raw material for the improvement of the rigidity and stability of rubber at high temperature during polypropylene plastic manufacture, talc raw materials should have low specific gravity, fine particle size distribution, softness and good colour [28]. The talcose rocks of the study area meet most of these criteria and will be useful if well processed. To be used in textile manufacture, talc raw materials are required to be free of hard/gritty particles (e.g. calcite, quartz), smooth, greasy, have good colour and moisture content < $0.3 \%$. Though the talc deposits in the study area are essentially free of gritty particles, are smooth and greasy; its colour may restrict its use to certain textile types/varieties. They should also be properly processed to remove potential impurities like chlorite and hornblende.

Although the talc content in the talc-chlorite schists of the study area are comparable with that of the Luzenac pharmaceutical grade talc deposit [21], due to the elevated concentrations of trace elements $(\mathrm{Ba}, \mathrm{Co}, \mathrm{Cr}, \mathrm{Cu}, \mathrm{Ni}, \mathrm{Pb}, \mathrm{Rb}, \mathrm{Sr}$, $\mathrm{V}$ and $\mathrm{Zn}$ ) in the talcose rock, which far exceed minimum risk levels prescribed by the Agency for Toxic Substances and Diseases Registry ([30]; Table 9), they 
Table 9. Comparison of trace element content of talc-chlorite schist with Recommended Daily Allowance of trace elements.

\begin{tabular}{cccc}
\hline Trace Elements $(\mathrm{ppm})$ & Mean & Range & MRL $(\mathrm{ppm})^{1}$ \\
\hline $\mathrm{Ba}$ & 20 & $8-38$ & 0.2 \\
$\mathrm{Co}$ & 76 & $65-88$ & 0.01 \\
$\mathrm{Cr}$ & 2486 & $1772-3290$ & 0.005 \\
$\mathrm{Cu}$ & 26 & $3-70$ & 0.01 \\
$\mathrm{Ni}$ & 1246 & $833-1568$ & $2{ }^{*} 10^{-7}$ \\
$\mathrm{~Pb}$ & 0.72 & $0.2-2$ & No safe threshold \\
$\mathrm{Rb}$ & 2 & $0.3-10$ & - \\
$\mathrm{Sr}$ & 12 & $5-35$ & 2 \\
$\mathrm{~V}$ & 48 & $33-65$ & 0.01 \\
$\mathrm{Zn}$ & 16 & $6-34$ & 0.3 \\
\hline
\end{tabular}

${ }^{1}[30]$.

are unsuitable as raw materials in the production of pharmaceutical and cosmetic products. They are however useful, if beneficiated, as industrial grade talc raw materials.

\section{Conclusion}

Talc-chlorite schists from Itagunmodi-Igun areas of the Ilesa schist belt contain talc and chlorite as major minerals, with accessory lizardite, hornblende and quartz. Results of chemical analyses indicate that the rocks are high in $\mathrm{SiO}_{2}$ and $\mathrm{MgO}$, with significant enrichments of $\mathrm{Co}, \mathrm{Cr}$ and $\mathrm{Ni}$. They plot within the komatiite field and are believed to derive from a peridotitic komatiite protolith. A comparison with talcose rocks from other parts of the Ilesa schist belt and southern Nigeria reveals similar silica content, lower magnesia and alumina, and higher ferric oxide components. They also compare favourably in talc composition with talc deposits from Luznac, France and in chlorite content with Lumphurm and Pitchbury talcose bodies. The mineralogical composition and physicochemical properties of the talc-chlorite schists make them suitable as raw material for paint, absorbent, coloured pottery, ceramic insulation, textile, rubber, plastic and roofing sheet manufacture with varying beneficiation requirements. The relatively high concentration of trace elements like $\mathrm{Cr}, \mathrm{Cu}, \mathrm{Ni}, \mathrm{Pb}$ and $\mathrm{Zn}$ however disqualifies them for use in pharmaceutical and cosmetic applications. The study has contributed to increased knowledge of the petrochemistry and petrogenesis of talcose bodies within the Nigerian schist belts (Ilesa in particular) and geology of the Basement Complex in general. Further work could involve an estimation of the tonnage of the talc deposit and the economic viability of mining it.

\section{Acknowledgements}

This study is part of the first/corresponding author's doctoral research, spon- 
sored by the African Union under the Pan-African University Initiative. The authors appreciate the constructive comments of the reviewers. O. G. Olisa is sincerely appreciated for his help during the field mapping exercise.

\section{References}

[1] Oyawoye, M.O. (1972) The Basement Complex of Nigeria. In: Dessauvagie, T.F.J. and Whiteman, A.J., Eds., African Geology, University of Ibadan Press, Ibadan, 6799.

[2] McCurry, P. (1976) The Geology of the Precambrian to Lower Palaeozoic Rocks of Northern Nigeria: A Review. In: Kogbe, C.A., Ed., Geology of Nigeria, Elizabethan Publishing Co., Lagos, 15-39.

[3] Rahaman, M.A. and Ajayi, T.R. (1988) Trace Element Geochemistry and Geotectonic Setting of Ile-Ife Schist Belt. Precambrian Geology of Nigeria, Geological Survey of Nigeria Special Publication, 241-256.

[4] Okunlola, O.A., Ogedengbe, O. and Ojutalayo, A. (2002) Compositional Features and Industrial Appraisal of the Baba-Ode Talc Occurrence, Southwestern Nigeria. Global Journal of Geological Sciences, 1, 63-72.

[5] Okunlola, O.A. and Anikulapo, F.A. (2006) Compositional Characteristics and Industrial Qualities of Talcose Rocks in Erin-Omu Area, Southwestern Nigeria. Journal of Mining and Geology, 42, 105-112.

[6] Ige, O.A. (1982) Mineralogy and Chemical Studies of Talc Bodies at Apomu, Western Nigeria in Relation to Their Industrial Properties. Unpubl. M.Sc. Project, University of Ibadan, $76 \mathrm{p}$.

[7] Durotoye, M.A. and Ige, O.A. (1991) An Inventory of Talc Deposits in Nigeria and Their Industrial Application Potentials. Journal of Mining and Geology, 19, 23-25.

[8] Bolarinwa, A.T. (2001) Compositional and Industrial Evaluation of Talc Bodies of Oke-Ila Area, Ilesa Schist Belt, Southwestern Nigeria. Mineral Wealth, 118, 48-52.

[9] Bolarinwa, A.T. and Adeleye, M.A. (2015) Petrogenesis and Functional Applications of Talcose Rocks in Wonu-Apomu and Ilesa Areas, Southwestern Nigeria. Materials and Geoenvironment, 62, 81-93.

[10] Elueze, A.A. and Akin-Ojo, O.A. (1993) Functional Characteristics of Talc Bodies in Southwestern Nigeria. Mineral Wealth, 85, 7-14.

[11] Olorunfemi, A.O., Olarewaju, V.O. and Okunlola, O.A. (2010) Petrochemistry and Genetic Indicators of Talcose Rocks of Esie Area, Southwestern Nigeria. Materials and Geoenvironment, 57, 363-386.

[12] Okunlola, O.A., Akinola, O.O. and Olorunfemi, A.O. (2011) Petrochemical Characteristics and Industrial Features of Talcose Rocks in Ijero-Ekiti Area, Southwestern Nigeria. Ife Journal of Science, 13, 317-326.

[13] Hubbard, F.H. (1975) Precambrian Crustal Development in Western Nigeria: Indication from the Iwo Region. Geological Society of America Bulletin, 86, 548-554. https://doi.org/10.1130/0016-7606(1975)86<548:PCDIWN>2.0.CO;2

[14] Folami, S.L. (1992) Interpretation of Aeromagnetic Anomalies in Iwaraja Area; Southwestern Nigeria. Journal of Mining and Geology, 28, 391-396.

[15] Woakes, M., Ajibade, C.A. and Rahaman, M.A. (1987) Some Metallogenetic Features of the Nigerian Basement. Journal of African Earth Sciences, 5, 655-664. https://doi.org/10.1016/0899-5362(87)90004-2

[16] Eleuze, A.A. and Awonaiya, F.A. (1989) Investigation of Talc Bodies in Iseyin Area, 
Southwestern Nigeria, in Relation to Their Application as Industrial Raw Materials. Journal of Mining and Geology, 25, 217-225.

[17] Elueze, A.A. and Ogunniyi, S.O. (1985) Appraisal of Talc Bodies of the Ilesa District, Southwestern Nigeria, and Their Potential for Industrial Applications. Natural Resources and Development, 21, 26-34.

[18] Jenson, L.S. (1976) A New Cation Plot for Classifying Subalkaline Volcanic Rocks. Ontario Geological Survey Miscellaneous Paper 66.

[19] Naldrett, A.J. and Cabri, L.J. (1976) Ultramafic and Related Mafic Rocks: Their Classification and Genesis with Special Reference to the Concentration of Nickel Sulfides and Platinum-Group Elements. Economic Geology, 17, 1131-1158. https://doi.org/10.2113/gsecongeo.71.7.1131

[20] Clarke, G.M. (1979) Talc-Density in Diversity. Industrial. Minerals. London, No. 144, 23-29.

[21] Luzenac Mines Report (2003) Quarterly Assessment Report. Luzenac Mines Limited, No. 215. 12 p.

[22] Macmillan, R.T. (1970) Mineral Facts and Problems. Bulletin 650, United States Bureau of Mines, 989-1000.

[23] Grogan, R.M. and Montgomery, G. (1973) Fluorspar and Cryolite. In: Lefond, J., Ed., Industrial Minerals and Rocks, Institute of Mining, Metallurgy and Petroleum Engineers, New York, 653-677.

[24] http://www.iso.org/

[25] Mitchel, L. (1975) Ceramic Raw Materials. In: Lethond, J., Ed., Industrial Minerals and Rocks, American Institute of Mining, Metallurgical and Petroleum Engineers, New York, 333.

[26] Severinghus, N. (1975) Fillers, Filters and Absorbents. In: Letond, J.S., Ed., Industrial Minerals and Rocks, publisher, Ney York, 125 p.

[27] American Texture Manufacturer's Institute (1975) Industrial Specification for Raw Materials in the Textile Industry, $54 \mathrm{p}$.

[28] Noble, P. (1988) Marketing Guide to the Paper and Pulp Industry. Fairfield, NJ, 148 p.

[29] American Society for Testing of Materials (1988) Handbook of Construction Materials, 45 .

[30] Agency for Toxic Substances and Disease Registry (ATSDR) (2012) Minimal Risk Levels. 